\title{
Chinese ways of being good Muslim: from the Cheng Hoo Mosque to Islamic education and media literacy
}

Rahmawati

IAIN Sultan Amai Gorontalo

E-mail: rahmatjatjo@iaingorontalo.ac.id

Kasim Yahiji

IAIN Sultan Amai Gorontalo

E-mail: kasimyahiji@iaingorontalo.ac.id

Choirul Mahfud

Institut Teknologi Sepuluh Nopember

E-mail: choirul.mahfud@its.ac.id

Jauharoti Alfin

UIN SunanAmpel

E-mail:alfin@uinsby.ac.id

Much. Koiri

Universitas Negeri Surabaya

E-mail:muchkoiri@unesa.ac.id

DOI: 10.18326/ijims.v8i2. 225-252 


\begin{abstract}
This article aims to explore the Chinese ways of being Muslim, from building the Cheng Hoo mosque to serving Islamic education and media literacy. In the current millennial disruption era, the role of communication media literacy in the contemporary Indonesian Chinese Muslim community needs to be studied further, especially its role in supporting the status of being good Chinese Muslim. This article is also intended to discuss the Chinese ways of fostering converts and Chinese Muslims through both communication media literacy and information technology literacy. Through media analysis method, communication media literacy is part of communication which is based on who says what, in which channel, to whom, with what effects. This research finds out that communication media literacy is used by the Indonesian Chinese Muslim community through the publication of Cheng Hoo magazine, WhatsApp Forum PITI Jatim, website, and Facebook. All of these media are used and have a significant effect on the relation, interaction, aspiration, and communication between the Chinese Muslim community and Chinese non-Muslim community, and the Chinese Muslim community with non-Chinese Muslims in Indonesia. Moreover, the Chinese ways of being good Muslims could also be understood from various ways in establishing Cheng Hoo Mosque, Islamic education services based on Chinese community from Kindergarten, Islamic Elementary School, Pesantren, and routine or regular discussions.
\end{abstract}

Artikel ini bertujuan untuk mengeksplorasi bagaimana cara-cara orang Tionghoa menjadi Muslim dari upaya pembangunan masjid Cheng Hoo hingga pelayanan pendidikan Islam dan literasi media. Di era disrupsi milenial seperti saat ini, peran literasi media komunikasi dalam komunitas Tionghoa Muslim di Indonesia kontemporer perlu dikaji lebih lanjut, khususnya perannya dalam mendukung menjadi muslim Tionghoa yang baik. Paper ini juga bertujuan untuk membahas cara Tionghoa dalam pembinaan mualaf dan Muslim Tionghoa melalui literasi media komunikasi dan teknologi informasi. Melalui metode analisis media, literasi media komunikasi merupakan bagian dari komunikasi yang berbasis pada siapa bicara apa, kapan, di mana dan melalui media apa serta apa dampaknya. Hasil penelitian menunjukkan bahwa literasi media komunikasi yang digunakan komunitas Tionghoa Muslim di Indonesia melalui penerbitan majalah Cheng Hoo, WhatsApp Forum PITI Jatim, Website dan 
Facebook. Semua media tersebut digunakan dan memiliki dampak signifikan bagi relasi, interaksi dan komunikasi antara komunitas Tionghoa Muslim dengan Tionghoa non-Muslim dan komunitas Tionghoa Muslim dengan nonTionghoa Muslim di negeri ini. Lebih dari itu, cara Tionghoa menjadi Muslim yang baik juga terlihat dalam beberapa pelayanan pendidikan Islam berbasis komunitas Tionghoa di Indonesia dari Taman Kanak-Kanak, Sekolah Dasar Islam, pengajian rutin, dan Pesantren.

Keywords: Muslim Chinese ways; Cheng Hoo Mosque; Islamic Education; Media literacy

\section{Introduction}

The Chinese ways of being a good Muslim are one of the interesting themes to be noticed in the era of millennial disruption. ${ }^{1}$ As a minority within Muslim minority, the Chinese Muslim community in Indonesia does not give up to perform various ways, strategies, and media literacy in the process of being a good Muslim. From the past until today, the Chinese ways of being Muslim have experienced contestation, sustainability, and change. $^{2}$ In the past, the Chinese way of being Muslim through the family line, marriage, and friendship. Now, the Chinese ways of being Muslim use quite a lot of approaches, strategies, relations, networks, and media. ${ }^{3}$ Chinese Muslims in contemporary Indonesia isgetting familiar

\footnotetext{
${ }^{1}$ Hew Wai Weng, Chinese Ways of Being Muslim: Negotiating Ethnicity and Religiosity in Indonesia, Copenhagen: NIAS Press, 2017, 18-39; Susan Mary Giblin, Being Chinese and Indonesian: Chinese Organisations in Post-Suharto Indonesia, $\mathrm{PhD}$ thesis, The University of Leeds Department of East Asian Studies, 2003, 12-18.

${ }^{2}$ Muhamad Ali, "Chinese Muslims in Colonial and Postcolonial Indonesia," Journal of Southeast Asian Studies, Volume 7,Number 2 (2007), 3-22; see Benedict Anderson, Imagined Communities: Reflections on the Origin and Spread of Nationalism, London: Verso, 1983, 121-140.

3 See Chang Yau Hoon, Chinese Identity in Post-Suharto Indonesia, Brighton: Sussex Academic Press, 2008, 118-123; Robert W. Hefner, Making Modern Muslim the Politic of Islamic Education in Southeast Asia, Honolulu: University of Hawai Press, 2009, 127-135.
} 
IJIMS: Indonesian Journal of Islam and Muslim Societies, Volume 8, Number 2, December 2018: 225-252

with information technology (IT), because those who embrace Islam are not only from older generation, but also from younger generation of Chinese Muslims.

This can be understood from the development of Chinese Muslims in Indonesia through magazine and media website, Instagram, and Facebook owned by the Chinese Muslim community. It can also be noted that through various information technology and social media, a number of religious teachers (ustadz) from the Chinese Muslim community have been creative and innovative in conveying the messages of Islam as part of the practice of preaching ( $\left.d a^{\prime} w a h\right)$ in the global era. Some of the ustadz who have actively presented in the study of Chinese Islam with the use of information technology media include Ustadz Haryono Ong, Felix Siauw, Ustadz Syaukani Ong, Ustadz Hasan, and others. This is done through YouTubevideo, Instagram, and television. Apparently, the digital era brings tremendous significant changes. ${ }^{4}$ There are different nuances compared to the previous year.

In the digital era, strategies and innovations in da'wah and learning Islam can be done through any media, including social media information technology. ${ }^{5}$ Lately, there are many fundamental issues and problems related to radicalism and terrorism, even suicide bombings in Surabaya. These various problems are suspected originally to have come from a wrong message (hoax) about da'wah via the internet. The contents of the da'wah message seem to be dominated by those that tend to spread hatred with one another. In this context, the Chinese Islamic community also think about its solutions and strategies by fostering themselves, organizations, and families.

${ }^{4}$ Jinghao Zhou, China's Peaceful Rise in a Global Context, Lanham-Maryland: Lexington Books, 2010, 103-117.

${ }^{5}$ Tim Lindsey and Helen Paulsacker (eds.), Chinese Indonesians: Remembering, Distorting, Forgetting, Singapore: Institute of Southeast Asian Studies, 2006, 12-38. 
The reason for the needs, wishes, and expectation of audiences on internet social media that require a good message of Islam is part of the supporting and attractive factors for Chinese Muslims to preach through various informations technology-based social media. ${ }^{6}$ Facing the millennial era and generation that begins to dominate all aspects of community life in Indonesia, Chinese Muslims also seem to understand the tendency of millennial society in every strategy and method of their da'wah. ${ }^{7}$ As it is known that Millennial generation (born between 1995 and now) is the generation that lives in the development of sophisticated digital technology, unlike X generation (1965-1976) and Ygeneration (1977-1994). According to Jamhari Makruf, the researcher from UIN Syarif Hidayatullah in Jakarta, Z generation is "open” to technology and society, but has an exclusive, conservative and not moderate tendency in religion. Irfan Abubakar from UIN Jakarta also assesses that this extreme viewpoint comes from the crisis of literacy and sources of religious knowledge that are not representative and authoritative. In this case, the Chinese Muslim community in Indonesia is also trying to understand the character and way of thinking of millennial society for the success of da'wah to the millennial group in ways that they can accept. ${ }^{8}$ This is a joint challenge for Islamic organization in Indonesia, including for Chinese Muslims in Indonesia.

The term 'millennial generation' has been popularized by British author Shelina Zahra Janmohamed in her latest book M Generation: Young Muslims Changing the World. In her writing, generation M is a generation

${ }^{6}$ See David M. Austin, Human Services Management, New York: Columbia University Press, 2002, 9-23.

${ }^{7}$ Marleen Dieleman, Chinese Indonesians and Regime Change,Koninklijke: Brill, 2010, 88-95; De Graaf and Pigeaud, Cina Muslim di Jawa Abad XV dan XVI, Yogyakarta: Tiara Wacana, 1997, 15-38.

${ }^{8}$ See Thomas Hylland Eriksen, Ethnicity and Nationalism, London: Pluto Press, 2002, 102-117. 
of global Muslims born from 30 years ago. The internet also becomes a platform for Muslims expressing their views, especially Muslim women. Muhadjir Effendy, the Ministry of Education and Culture of the Republic of Indonesia, states that millennial Muslims now have demonstrated their ability as young Muslims who are inclusive, open minded, and armed with 5C: critical thinking, innovativeness, communication skill, collaboration, and confidence.

In this context, Chinese Muslims also realize that this of Millennial Muslims phenomenon presents not only the latest reality but also how to strategically face a new era. Religion may not change, but time has changed. This Millennial Muslim is important to understand for anyone who wants to become a good Chinese Muslim who is able to adapt to the changing time, without losing the identity and character of Chinese Islam. ${ }^{9}$

\section{Being good Muslim}

Rhenald Kasali states that the world today is facing the phenomenon of disruption. ${ }^{10}$ The change is very fast and fundamental. ${ }^{11}$ The era of millennial disruption also initiates the birth of a new model with a more innovative and disruptive strategy in various fields of life. The scope of change is wide--ranging from the world of business, banking, transportation, social community, to education and religion. This era requires us to change or become extinct. ${ }^{12}$ Through a Muslim minority that influences and connects with world leaders, with the power of inspirational faith and resistance to the status quo, Generation $\mathrm{M}$ is

\footnotetext{
${ }^{9}$ Aimee Dawis, Orang Indonesia Tionghoa Mencari Identitas, Jakarta: Gramedia, 2010,
} 88-99.

${ }^{10}$ Rhenald Kasali, Disruption, Jakarta: Gramedia Pustaka Utama, 2017, 118-123.

${ }^{11}$ Norman Fairclough, Discourse and Social Change, Cambridge: Polity Press, 2010, 7-19.

${ }^{12}$ Azyumardi Azra,The Origins of Islamic Reformism in Southeast Asia: Networks of MalayIndonesian and Middle Eastern Ulama' in the Seventeenth and Eighteenth Centuries, Honolulu: University of Hawaii Press, 2004, 16-33. 
determined to make changes. And such an identity change is happening now. ${ }^{13}$

The era of disruption is strongly influenced by information technology. Therefore, the innovation that is needed changes not only shape, size, or design, but overall, both method, method of work, and products that are no longer relevant in the millennial era. ${ }^{14} \mathrm{No}$ doubt, the disruption will encourage the digitalization of the Islamic education system and religious community. This principle marks the beginning of the democratization of knowledge which creates opportunities for us to utilize the technology more productively.

Until now, various Chinese ways of being good Muslims are carried out throughmore integrative new way between building of Cheng Hoo mosque in several major cities in Indonesia and organizing Chinese community-based Islamic education in Indonesia from Kindergarten, Islamic Elementary School, regular recitation, and Islamic boarding school (pesantren), to publishing Cheng Hoo magazine and news publication through website and interaction through social media such as Facebook, YouTube, WhatsApp, and Instagram. All of these efforts are carried out to safeguard old traditions and a new tradition to strengthen the character and identity of Chinese Muslims in contemporary Indonesia.

\section{Cheng Hoo Mosque: an Islamic Chinese center}

One of the Chinese ways of being good Muslim is through Cheng Hoo mosque development program in several major cities in Indonesia. There are many reasons why the Cheng Hoo mosque development projects are established in various cities in Indonesia. One of the few noble reasons is to negotiate the Muslim identity of the Chinese and maintain the

\footnotetext{
${ }^{13}$ Ariel Heryanto (ed.), Pop Culture in Indonesia, London: Routledge, 2008, 122-136.

${ }^{14}$ Raymond Firth, Symbols: Public and Private, Ithaca: Cornell University Press, 1975, 23-38.
} 
continuity of the formation of Chinese Muslims in Indonesia, which are increasing day by day. ${ }^{15}$ Every year, the number of Chinese Muslims in Indonesia continues to grow and increase rapidly. Chairman of the Haji KarimOei Foundation (YHKO), Muhammad Ali Karim Oei explains that the development can be seen and influenced by a large number of mosque development established by Chinese Muslims in Indonesia. He cites the Cheng Hoo Mosque in a number of major cities in Indonesia, including in Surabaya, Jakarta, Pasuruan, Jember, Banyuwangi, Malang, Palembang, and others.

In Surabaya, Chinese Muslims have the Cheng Hoo mosque Surabaya. In Jakarta, Chinese Muslims also have the Laotze Mosque, which is considered a representation of Chinese and Islamic culture. The existence of these mosques is not only limited to a place of worship but also becomes the center of da'wah activities and the syiar of Chinese Muslims. Ali Karim states that currently Chinese Muslims already have mosques. The development has also been quite a lot from day to day.

According to Ali Karim, with many constructions of mosques have a significant influence on the acceptance of non-Chinese Muslim community to Chinese Muslims in Indonesia. ${ }^{16}$ Integration and social relations with the community occur more easily. Even non-Chinese Muslims are quite happy to find Chinese people who join Islam. Moreover, some Chinese Muslim preachers or ustadz perform in public area a positive image of the existence of the Chinese Muslim community. Cheng Hoo Mosque is the first mosque in Indonesia that uses Chinese name and

15 See Akhmad Muzzaki, "Negotiating Identity: The Cheng Hoo Mosque and The Ethnic Chinese Muslim in Post-Soeharto Indonesia," Chinese Southern Diaspora Studies, Volume 3 (2009): 1-8; Choirul Mahfud, "The Role of Cheng Ho Mosque: The New Silk Road, Indonesia-China Relations in Islamic Cultural Identity," Journal of Indonesian Islam, Volume 8, Number 1 (2014): 23-25.

${ }^{16}$ John Naisbitt \& Doris, China's Megatrends, Jakarta: Gramedia Pustaka Utama, 2010, 18-58. 
has a unique architecture such as pagoda with distinctive yellow and red colors. The mosque is located on Jalan GadingNo. 2 Surabaya which was initially built on 15 October 2001, based on the idea of HMY Bambang Sujanto and friends of PITI (Indonesian Chinese Islamic Union). The initial design of the Cheng Hoo Mosque in Indonesia was inspired by the shape of the Niu Jie Mosque in Beijing China, which was built in 996 AD. The mosque has typical Chinese architecture with a roof like the Khonghuchu pagans commonly found in Indonesia. The existence of Niu Jie Mosque in China and Cheng Hoo Mosque in Indonesia proves that Islam is able to blend well with the local culture. ${ }^{17}$ In history, Islam entered Indonesia also being brought by preachers from China, namely a Muslim admiral named Cheng Hoo. ${ }^{18}$

The main reason for the architecture of the Cheng Hoo Mosque resembling the pagoda model is the idea to show the character and identity of Chinese Muslims in Indonesia and to commemorate the Chinese ancestors who are predominantly Buddhists and Khonghucu. The threetiered Cheng Hoo mosque roof symbolizes Faith, Islam, and Ihsan, which are the levels of faith that is the foundation of Muslims in the world. The roof is in the shape of an 8-shape with a tapered tip in every corner, is an important element of Chinese culture, especially Buddhists who symbolize the 8 paths of truth, glory, and luck. As stated by Nurawi, the purpose of the establishment of the Chinese Muslim community, PITI, and Cheng Hoo Mosque is to form so that Chinese converts can have a place, a place for Chinese people. In general, the majority of Chinese people are nonMuslims, Muslims are a minority. They establish a mosque to gather a place to study Islam or coach and deepen religion. ${ }^{19} \mathrm{He}$ also emphasizes

17 See Merle Calvin Ricklefs, A History of Modern Indonesia, London: Macmillan Education, 1988, 18-45.

${ }^{18}$ Ust.Hasan Basri, interview, Office YHMCHI, 7 November 2017.

${ }^{19}$ Fahmi R. Perdana, Integrasi Sosial Muslim Tionghoa, Yogyakarta: Mystico-PITI Korwil 
that when the minority Chinese Muslims feel to be discriminated, they need a form of association that is in their faith. ${ }^{20}$ So they do not feel alone anymore and depressed until they decide to return to their previous religious understanding. However, it does not mean that Cheng Hoo Mosque belongs only to minority Chinese Muslims. The mosque also becomes a place and belongs to other Muslims from Javanese, Sumatra, Medan and Papua ethnic groups. Because Cheng Hoo Mosque stands in the country of Indonesia which is famous for its various ethnicities and cultures with its motto 'unity in diversity.' It is not fitting if the Cheng Hoo mosque is not open to people of different backgrounds.

Until now, the construction of Cheng Hoo mosque in several major cities in Indonesia continues to be built. Recently, in Malang, Cheng Hoo Gua China Mosque was launched. In this context, in addition to religious rituals, Cheng Hoo mosque also has a lot of functions; it is supported by many facilities, multi-purpose buildings, basketball courts, badminton courts, cafes, shops whose function is to support the economy and operation of the mosque and its employees. What is quite interesting is that Cheng Hoo Mosque in Surabaya can exist and develop because it is also supported by several non-Muslim businessmen besides Chinese Muslim entrepreneurs. Some portraits of Cheng Hoo mosque roles, contributions, and programs are part of the Chinese ways of being good Chinese Muslims in Indonesia, which now deserve to be appreciated by many parties, including the government, the community, and the Chinese themselves.

\section{Establishing Cheng Hoo Islamic education}

The Chinese ways of being good Muslims are also done through the development and establishment of Islamic education, from kindergarten,

Yogyakarta, 2008, 15-25.

${ }^{20}$ Junus Jahja (ed.), Zaman Harapan Bagi Keturunan Tionghoa, Jakarta: Yayasan Ukhuwah Islam, 1984, 3-11. 
elementary school to pesantren. Chinese Muslim community realizes that education is a new silk line to maintain good relations between Indonesia and China. Moreover, education is a strategic medium to instill the values of goodness as a good Muslim. ${ }^{21}$ At present, the Chinese Muslim community in Surabaya has schools from kindergarten to Chinese Islamic elementary school. Kindergarten and playgroups are built by the Chinese Muslim community in Surabaya called Istana Balita (kinder garden, hereafter IsBa) Cheng Hoo. This school is located behind Cheng Hoo Mosque. According to the Chairman of YHMCHI, Abd. Nurawi, the education system in IsBa Cheng Hoo emphasizes the importance of providing a quality education that is balanced between children's academic achievement and the strengthening of their noble character. This school applies the use of 4 languages, namely English, Arabic, Mandarin, and Indonesian. This school is open to the public, not only for Chinese families. Beside Isba, the Chinese Muslim community in Surabaya also established integrated Islamic elementary school (SDIT) Cheng Hoo, in early January 2017. The school is located on Jl. Telasih No. 20, just right behind Cheng Hoo mosque. As with Isba, SDIT Cheng Hoo employes 4 languages: English, Mandarin, Arabic, and Indonesian.

In particular, the vision of Kindergarten of Istana Balita Cheng Hoo is to form a generation that is noble, intelligent, creative and independent. Meanwhile,the mission of Kindergarten of Istana Balita Cheng Hoo are: to create character education from an early age; to carry out creative learning; to familiarize independent children; to make child achievement.

Regarding the vision of integrated Islamic elementary school (SDIT) Cheng Hoo, which is to make the generation of Islam as a smart, agile, pious, knowledgeable and Quranic generation. The mission SDIT Cheng Hoo: to empower active, creative, effective, innovative and fun learning,

\footnotetext{
${ }^{21}$ Robert W. Hefner, Making Modern Muslim..., 19-29.
} 
to realize achievement; to develop the field of science and technology based on the interests and potential of students; to embed Faith and Taqwa through the experience of religious teachings; to intensify the development of life skills towards independence; to create a conducive, safe, comfortable school atmosphere for the formation of the personality of students who have faith and piety; to develop the spirit of achievement and to realize an honest, sporty competitive culture for all school residents in competing for achievement; to develop the ability to communicate in four languages (Indonesian, Arabic, English, and Mandarin); 8. to introduce modern technology facility towards globalization.

The educational program developed by the Chinese Muslim community attracted many parties. In fact, the US Ambassador was also impressed by Cheng Hoo Kindergarten and SDIT Students. During his visit to Cheng Hoo Mosque Surabaya, the US Ambassador to Indonesia Joseph R. Donovan Jr., Wednesday (05/09/2018), expressed his appreciation. At the Cheng Hoo Education complex, the Ambassador had a chance to chat with a number of kindergarten students who were practicing dance. The Ambassador also took pictures with a number of students and teachers. A happy expression appeared on the Ambassador and other guests. Before visiting the Cheng Hoo School, the Ambassador said that Cheng Hoo Mosque Surabaya is a portrait of the success of tolerance that needs to be appreciated by all of us. Especially in protecting minority groups, the United States certainly welcomes this role positively.

Meanwhile, H. A. Nurawi said that the cooperation built by the US Ambassador has produced several agreements, one of themis student exchange. According to him, in November 2017, one of Cheng Hoo's ustadz was invited to America to learn about the perception of religious and cultural togetherness for more than three weeks. According to him, this is one effort that is built together between Cheng Hoo Mosque 
Surabaya and the United States Government to equate the perception of religious and cultural diversity in Indonesia. ${ }^{22}$ According to him, Islamic culture, in every country is different but the substance is the same. Previously, Herman Halim explained that the history of the Cheng Hoo Mosque in Surabaya, especially about the history of development, carried out in cooperation. Herman also explained that tolerance and togetherness continue to be built. ${ }^{23}$

The same thing but different form is interfaith harmony in Banyuwangi Regency. In the midst of widespread ethnic, religious, racial and interethnic (SARA) issues, local community and Chinese citizen together established mosque and pesantren educational institution, namely Muhammad Cheng Hoo Mosque and Islamic Boarding School of Adz-Dzikra Muhammad Cheng Hoo. The mosque and the pesantren educational institution stand on an area of 2.5 hectares. The construction donors come from the local community, Chinese citizen, and the Indonesian Chinese Islamic Association (PITI) East Java. This step is a form of da'wah to the community while upholding religious harmony in Indonesia.

\section{Chinese Islamic media literacy}

The Chinese ways of being good Muslim can also be understood from several developments in information and technology media literacy

22 Interview with H.A. Nurawi, Surabaya, 18 November 2017. For understanding more about building peace and harmony in social life, see Zakiyuddin Baidhawy, "Building Harmony and Peace through Multiculturalist Theology-Based Religious Education: an Alternative for Contemporary Indonesia”, British Journal of Religious Education,volume 29, number 1 (2007), 15-30; Hilman Latief, Melayani Umat, Jakarta: PT Gramedia Pustaka Utama, 2010, 11-41.

${ }^{23}$ Interview with Herman Halim, Surabaya, 11 November 2017. In strengthening cooperation, tolerance and togetherness, and understanding more about distributive principles of economic justice in creating harmony and welafe society, please see Zakiyuddin Baidhawy, "Distributive Principles of Economic Justice: an Islamic Perspective", Indonesian Journal of Islam and Muslim Societies, volume 2, number 2 (2012), 241-266. 
programs in the Chinese minority Islamic community in Indonesia. ${ }^{24}$ In the era of globalization of information and technology as it is today, the agenda of propagating Chinese Islam is carried out in many ways and media. ${ }^{25}$ Both through the publication of Cheng Hoo magazine and social media publication such as Facebook, WhatsApp, Instagram, and Website.

It is realized that the phenomenon of the proliferation of Islamic media in this country is on the one hand quite encouraging, but also unsettling on the other side, especially in the aspect of an ideology of reporting in the Islamic media in Indonesia after the reformation. ${ }^{26}$ Harold D. Laswellever stated that the key of effective communication or in our language can be called effective da'wah, including not being separated from the element "who says what which channel, media and what effects". Laswell's statement seems relevant to reflect upon understanding, sorting and choosing the characteristics of Chinese Islamic media in Indonesia as a reference and the consumption of Chinese reading and Islamic studies.

Before understanding more about the Chinese Islamic media literacy, here it needs to be understood in advance that, in general, the Islamic mass media typology in Indonesia can be categorized into two types: Firstly, prophetic journalism; Secondly, provocative journalism. The first type leads to an idealism that the prophetic journalism model is that seeks the dissemination of information and news with the use of language that is more friendly, polite, peaceful, soothing, and dialogical. ${ }^{27}$ Moreover, they

\footnotetext{
${ }^{24}$ Ahmad Suaedy (et.al.), Islam dan Kaum Minoritas: Tantangan Kontemporer, Jakarta: The Wahid Institute, 2012, 15-22.

${ }^{25}$ Chang Yau Hoon, Chinese Identity..., 18-58.

${ }^{26}$ Chi Kim Cheung \& Wen Xu, Promoting Media Literacy Education in China: a Case Study of a Primary School, International Journal of Adolescence and Youth, volume 21, number 2 (2016), 215-217.

27 The term of prophetic journalism related to the prophetic social sciences that
} 
also find more enlightenment, education, peace, and open-mindedness to understand the substance of Islam essentially. ${ }^{28}$

In this context, the content of news quality is more prominent than the issue of Islamic ideology alone. This type is also the aim of peace building-oriented, anti-violence and anti-conflict. The spirit of jihad builds a pluralistic and multicultural society that is very prominent while voicing progressiveness, liberalism, and anti-radicalism.

The second type of journalism, namely; provocative journalism. This second type can be understood from the use of language and the presentation of news conducted by leaders and editors of Islamic media which tend to be more normative, provocative, intimidating to antidialogical. The media like this is the opposite of the prophetic journalism media. The characteristics and language of this media appear provocative and spread hostility and invite conflicts. At the first glance the mapping above, it can be understood that the existence and contribution of Islamic media are not single. The presence of Chinese Islamic media called Cheng Hoo magazine and now developed in cyberspace on the website chenghoo.co, can be understood as a new media in the Islamic treasury in Indonesia and includes a type of prophetic journalism, because it presents good news.

In general, we actually understand that the Islamic media in Indonesia also has their own idealism, which is to give the correct information as a discursive space. ${ }^{29} \mathrm{~W}$ ith such idealism, the Islamic media also wants to act

focus on creating and transforming peaceful and harmonious society, please see Pradana Boy ZTF, "Prophetic Social Sciences: Toward an Islamic-Based Transformative Social Sciences," Indonesian Journal of Islam and Muslim Societies, Volume 1, Number 1 (2011), 95-121.

${ }^{28}$ Masdar Hilmy, “Whither Indonesia’s Islamic Moderatism?”, Journal of Indonesian Islam, Volume 7, Number 1 (2013), 24-48.

${ }^{29}$ Khoirun Niam, "The Discourse of Muslim Intellectuals and Ulama'in Indonesia: A Historical Overview”, Journal of Indonesian Islam, volume 4, number 2 (2010), 287-316. Also 
as a means of education. Viewers, readers, and listeners will increasingly have a critical attitude, independence, and depth of thinking. However, the reality often has the opposite direction. The abstract of reality is greatly colored by the structure of economic meaning that perceives that idealism. In another perspective, Haryatmoko explained that commercial dynamism seems to be a dominant force in determining meaning, message and beauty of the media, including Chinese Islamic media. ${ }^{30}$

Market logic directs the organization of information system. Many media leaders from the corporate world want to justify the market logic. As if the journalism competence is only a factor of production whose main function is to support market interests. ${ }^{31}$ This market reality illustrates how the media is under the pressure of tough and tight economic-ideology of competition. Therefore, the Chinese Islamic Media in Indonesia as a new media that is pioneered and developed also seems to have tried to be aware of the values and spirit of Islamic media that have existed so far. Hopefully, the Chinese Islamic media will be an alternative and exclusive solution for Chinese people to be good Muslims.

\section{Chinese Islamic media: an alternative}

When the market is dominated by Islamic media which voices fanaticismexclusivism (provocative journalism), Chinese Islamic media is now emerging as an alternative to answering the needs and expectation of Chinese Muslims in Indonesia. As we know, there are many assumptions in the Chinese Muslim community in assessing the existence of information from Islamic media in Indonesia.

In general, the content of the message of media delivered is not

see I. Wibowo (ed.), Harga yang Harus Dibayar, Jakarta: Gramedia Pustaka Utama, 2000, 88-99.

${ }^{30}$ See Haryatmoko, Etika Komunikasi, Yogyakarta: Kanisius, 2007, 18-19.

${ }^{31}$ Haryatmoko, Etika..., 23-38. 
suitable, not to mention the quality and ideality of the media which tends to be provocative. This is certainly a concern because Indonesian Islamic media published since that time has been dominated by the media which tends to sell "hatred-news". ${ }^{32}$ Even though we know, the media is a crucial factor for the formation of images, frame, and stigma of Islam in Indonesia from time to time. ${ }^{33}$ It is from the media that we get information about the reality that is taking place elsewhere. ${ }^{34}$ Meanwhile, the reality that the media presents to us is not necessarily the real reality, but the reality that has been formed, framed and polished in such a way by the media. Through framing analysis, we know how secretly the media dictates our brain about "reality" without our knowing.

The concept of framing is often used by the media to describe an event by highlighting certain aspects and at the same time placing information in a specific context so that certain issues get greater allocation and attention than other issues. ${ }^{35}$ In practice, framing is carried out by the media by selecting certain issues while ignoring other issues; highlighting certain aspects of the issue while hiding and even removing other aspects. This is done starting from the planning process, field data collection, data verification, and selection, presentation in the form of news, to placement in a particular rubric. Perhaps that is why a very famous American political journalist, Walter Lippmann, said that between news and truth are two different things and must be clearly differentiated. In

${ }^{32}$ See Agus Sudibyo, Ibnu Hamaddan, M. Qodari, Kabar-kabar Kebencian, Jakarta: ISAI, 2001, 5-18.

33 Ahmad Najib Burhani, "Defining Indonesian Islam: An Examination of the Construction of National Islamic Identity of Traditionalist and Modernist Muslims", in Islam in Indonesia, edited by Jajat Burhanuddin and C. van Dijk, Amsterdam: Amsterdam University Press and ICAS, 2013, 25-48.

${ }^{34}$ Hans Kung, Global Responsibility In Search of a New World Ethic, New York: Crossroad Publishing Company, 1991, 12-35.

${ }^{35}$ Francis Fukuyama, Trust: The Social Virtues and The Creation of Prosperity, New York: The Free Press, 1995, 126-133. 
fact, he said, even in the tradition of a very professional American press, there is an expression, "We formulate more often then look for news, rather than find news first and then formulate". ${ }^{36}$

If we read Islamic media published shortly after the fall of the New Order in Indonesia, it will soon be seen how the concept of framing is applied almost perfectly in almost every news. These media present news that emotionally directs people's consciousness. Sabili magazine, for example, is read not only by Muslims but also non-Muslims. Consider the reason for Catholic readers who always faithfully buy Sabili magazine: "I really enjoy the nuances of hostility displayed by Sabili." Then, the next question is, why does moderate Islamic media recede when the market is dominated by Islamic media (war journalism) which only sells hatred and hostility? There is indeed a kind of market assumption that the Islamic media is not something marketable. But this assumption is broken by the Sabili success story.

There is another assumption that moderate Islam is not an interesting theme for sale. This assumption is broken by the success story of Panji Masyarakat, Ummat, and Ulumul Qur'an. The failure of these three Islamic media to maintain is management factors. What is selling is not only quality media, but also those that are published first. Quality assurance and time can only be fulfilled by reliable management, things that are rarely found in Islamic media, including in Chinese Islamic media.

Management factor surely becomes a serious problem in the management of Islamic media, including Chinese Islamic media in Indonesia. Management here is not solely in the sense of company management, where the entire management of the company's resources are fully oriented to produce quality products to meet competition standard, but also in the sense of editorial management, where the attractiveness of events, news quality, data accuracy and validity, and the credibility of

\footnotetext{
${ }^{36}$ Walter Lippmann, Opini Umum, Jakarta: Yayasan Obor Indonesia, 1998, 15-23.
} 
the resource person is processed and presented into a compelling news. This is certainly not an easy job for the Chinese Muslim community. Moreover, electronic-radio, media, television, and the internet have provided information in a way that is much cheaper, easier and faster. Therefore, the challenge of the Chinese Islamic media as a moderate Islamic media lies not only in how to fix corporate management and editorial management but also in how to give "more value" to readers who are increasingly intelligent today. And this value can only be fulfilled if the "enticing presentation" is balanced by the increasing quality of the presented content.

In other perspective, Khaleed A. El Fadl in his work"The Great Theft: Wrestling Islam from the Extremists", suspected that whether it is realized or not, the success story of fundamentalist radicals through various other Islamic media cannot be separated from the "silence" of moderate Islamic groups in various regions, including in Indonesia. ${ }^{37}$ Therefore, the development movement of Chinese Islamic media in this country also needs to be continuously improved and optimized to provide a portrait of Islam in Indonesia. Optimizing the more moderate Chinese Islamic media can minimize the potential for radicalism. The potential for violence carried out by any media can be huge, including in the news.

Stanley indicated that there is a practice of provocative journalism through various attempts to twist facts by delivering news with sources that could not be accounted for the truth unless it only relies on the legitimacy of the position. The practice of provocative journalism is usually also done by presenting headlines and different news title (misleading) with the content of news to the actual reality. A number of media also carry out dramatization and hardening of facts to inflame

${ }^{37}$ Khaleed Abou El Fadl, The Great Theft; Wrestling Islam from the Extremists, New York: Harper-Collins Publishers, 2005, 118-139. 
hatred and hostility to provocation to do violence and the like. Quoting words is done precisely by choosing the loudest and most controversial sources' words that can cause open conflicts.

In this context, readers are required to be critical, and newsmakers and Islamic media institution need to crosscheck and clarify continuously so that they are sure of the validity of the information obtained. Moreover, it is the time for the ethics of communication to be upheld together. Without ethics, of course, the information can lead to immoral acts. In this case, communication ethics functions to dismantle these forms of domination by inviting the audience/reader to take the distance. The communication ethics grow awareness to criticize the media which today tends to make compulsive viewers so that reflection is ignored for the sake of emotion. Information is an interpretation. In this case, the presence of Chinese Islamic media is part of an alternative solution for Chinese Muslims in Indonesia.

\section{Cheng Hoo Magazine as prophetic journalism}

The Chinese Muslim community in Surabaya published Cheng Hoo magazine. This Cheng Hoo magazine was originally called "Komunitas" magazine. When it is understood from the perspective of prophetic journalism and provocative journalism, Cheng Hoo magazine for the Chinese Muslim community is part of prophetic journalism. Prophetic journalism is the opposite of provocative journalism. Practically, in the prophetic journalism is upheld in the journalism ethics which leads to accuracy, data-and-fact validation with a more polite and even educative and inspiring reporting model. In this context, Cheng Hoo magazine for the Chinese Muslim community in Indonesia has a mission as prophetic journalism to have a positive impact on efforts to enlighten, awaken, and 
inspire the Chinese Muslims to be good Muslims. ${ }^{38}$

Substantially, Cheng Hoo Magazine has a lot of Islamic information and messages that can inspire the Chinese Muslims. ${ }^{39}$ Parni Hadi, a former editor of Republika, stated that prophetic journalism in the Islamic media underlies the universal nature of the Prophet, such as Shiddiq, Tabligh, Amanah, and Fathonah. According to him, these four things are in every code of ethics. Still according to him, the Islamic media does not always have to use names that show Islamic identity, such as Al-Jihad or there is an Islamic appendage behind the name of the media concerned. For Parni, the importance is content. The name is important, but the content is more important. Like Al-Jazirah, the content and management show high quality. That is why al-Jazirah succeeds. Parni hopes that Islamic media in Indonesia needs to prioritize quality. ${ }^{40}$ The public is now certainly smarter in choosing, sorting, and consuming the existing Islamic media, whether the Islamic media that is read has an impact on Islamic awareness and enlightenment or vice versa. The public is now also more rational in assessing the content of the news presented.

Cheng Hoo magazine as an Islamic media published by the Chinese Muslim community is a solution and counter-discourse on the various negative news about Islam. Actually, Cheng Hoo magazine is published for internal consumption of Chinese Muslims. However, Cheng Hoo magazine is now also a reference for reading to the non-Chinese Muslim community in Indonesia, because this magazine is also shared or distributed to all non-Chinese Muslim leaders in Indonesia. As an

38 See Majalah Cheng Hoo, Majalah Dwi Bulanan Komunitas Muslim Tionghoa, number 92 (2017), 5-9; Majalah Cheng Hoo, number 93 (2017); Majalah Cheng Hoo, number 94 (2017), 11-17; Majalah Cheng Hoo, number 95 (2017), 8-19.

${ }^{39}$ James Donald Rattansi, and Ali Rattansi, Race, Culture, and Difference, London: Sage Publications, 1992, 11-19.

${ }^{40}$ James Donald Rattansi, and Ali Rattansi, Race, Culture..., 17-54. 
alternative media, Cheng Hoo magazine has a role as a counter-discourse and news about Islam in Indonesia and the world, because lately, a number of Western mass media have made Islam as a target object in the reporting of terrorism and suicide bombing.

The presence of Cheng Hoo magazine as an alternative media is an important answer to peace. Presenting friendly and polite Islamic media is essential and in accordance with the characteristics of Islam in Indonesia through Islamic media literacy conducted by Muslims in Indonesia, including Chinese Muslims. Ideally, contemporary journalism still considers the cover bothside aspects. ${ }^{41}$

In this context, the best solution of the various choices of Islamic media ideology in Indonesia is the agenda of setting up transformative Islamic da'wah, today and tomorrow, which is no other than the idealistic choice in the prophetic journalism model that seeks for the dissemination of information and news with the use of more friendly polite, peaceful, soothing and dialogical language. Moreover, it should preach educational, informative, and inspirational messages. It is expected that the people will find enlightenment, education, peace, and open-mindedness to understand the substance of Islam essentially. Here, the content of news quality is more prominent than the issue of Islamic ideology alone. The choice of the prophetic journalism model will certainly be the choice and homework for the Chinese Islamic community in Indonesia on the agenda of their da'wah today and tomorrow.

\section{Conclusion}

In this study, the Chinese ways of being good Muslims experience the change and sustainability in accordance with the changes in the millennial era, starting from the construction of Cheng Hoo mosque in

\footnotetext{
${ }^{41}$ Djaffar Assegaff, Jurnalistik Masa Kini, Jakarta: Ghalia Indonesia, 1991, 112-127.
} 
several major cities in Indonesia, up to establishing Cheng Hoo Islamic education, pesantren and developing Islamic media literacy movement which is typical of Indonesian Chinese Muslims. Interestingly, Chinese Muslims in Indonesia also maintain good old tradition, identity, and culture. Moreover, it also makes new ways and strategies to answer the needs, wishes, and public expectation of the Chinese Islamic community in particular and Muslims in Indonesia in general by building dialogue, communication, and media literacy.

\section{Bibliography}

Abdullah, Taufik ed. Agama dan Perubahan Sosial. Jakarta: Rajawali Press, 1983.

Afif, Afthonul. Identitas Tionghoa Muslim Indonesia: Pergulatan Mencari Jati Diri.Depok: Penerbit Kepik, 2012.

Ali, Muhamad, "Chinese Muslims in Colonial and Postcolonial Indonesia,"Journal of Southeast Asian Studies, volume 7, number 2 (2007): 3-22.

Anderson, Benedict. Imagined Communities: Reflections on the Origin and Spread of Nationalism. London: Verso, 1983.

Arief, Khozyn. Sejarah dan Perkembangan PITI: Kiprah PITI di Gelanggang

Nasional. Buku Panduan Seminar dan Musyawarah Wilayah PITI Yogyakarta, 1994.

Assegaff, Djaffar. Jurnalistik Masa Kini. Jakarta: Ghalia Indonesia, 1991. Azra, Azyumardi. Jaringan Ulama Timur Tengah dan Kepulauan Nusantara Abad XVII-XVIII. Jakarta: Kencana Prenada Media Group, 2013. Azra, Azyumardi. The Origins of Islamic Reformism in Southeast Asia: Networks of Malay-Indonesian and Middle Eastern Ulama' in the Seventeenth and Eighteenth Centuries. Honolulu: University of Hawaii Press, 2004.

Baidhawy, Zakiyuddin, "Building Harmony and Peace through Multiculturalist Theology-Based Religious Education: an Alternative for Contemporary Indonesia," British Journal of Religious Education, volume 29, number 1 (2007): 15-30.

Baidhawy, Zakiyuddin, "Distributive Principles of Economic Justice: an 
IJIMS: Indonesian Journal of Islam and Muslim Societies, Volume 8, Number 2, December 2018: 225-252

Islamic Perspective," Indonesian Journal of Islam and Muslim Societies, volume 2, number 2 (2012): 241-266.

Budiman, Amen. Masyarakat Islam Tionghoa di Indonesia. Semarang: Tanjung Sari, 1979.

Burhani, Ahmad Najib, "Defining Indonesian Islam: An Examination of the Construction of National Islamic Identity of Traditionalist and Modernist Muslims" in Islam in Indonesia: Contrasting Images and Interpretations, edited by JajatBurhanuddin and C. van Dijk, Amsterdam: Amsterdam University Press and ICAS, 2013: 25-48.

Chua, Christian. Chinese Big Business in Indonesia: The State of Capital. London: Routledge, 2008.

Cheung, Chi Kim \& Wen Xu, "Promoting Media Literacy Education in China: a Case Study of a Primary School", International Journal of Adolescence and Youth, volume 21, number 2 (2016): 215-217.

Dawis, Aimee. Orang Indonesia Tionghoa Mencari Identitas. Jakarta: Gramedia, 2010.

De Graaf dan Pigeaud. Cina Muslim di Jawa Abad XV dan XVI. Yogyakarta: Tiara Wacana, 1997.

Dewi, Fitriana Utami. Public Speaking: Kunci Sukses Bicara di Depan Publik. Yogyakarta: Pustaka Pelajar, 2013.

Dieleman, Marleen. Chinese Indonesians and Regime Change. Koninklijke: Brill, 2010.

Dreyer, Edward L. Zheng He: China and the Oceans in the Early Ming Dynasty, 1405-1433. New York: Pearson Longman, 2007.

Eriksen, Thomas Hylland. Ethnicity and Nationalism. London: Pluto Press, 2002.

Fairclough, Norman. Discourse and Social Change. Cambridge: Polity Press, 2010.

Firth, Raymond. Symbols: Public and Private. Ithaca: Cornell University Press, 1975.

Fukuyama, Francis. Trust: The Social Virtues and The Creation of Prosperity. New York: The Free Press, 1995.

Gernet, Jacques. A History of Chinese Civilization. Cambridge: Cambridge University Press, 1997.

Giblin, Susan Mary, "Being Chinese and Indonesian: Chinese 
Organisations in Post-Suharto Indonesia', Ph.D thesis, The University of Leeds Department of East Asian Studies, 2003.

Giddens, Anthony. The Consequences of Modernity. Stanford: Stanford University Press, 1990.

Giddens, Anthony. The Third Way and its Critics. Cambridge: Polity Press, 2000.

Haryatmoko. Etika Komunikasi Manipulasi Media, Kekerasan dan Pornografi. Yogyakarta: Kanisius, 2007.

Hefner, Robert W. Civil Islam, Muslims, and Democratization in Indonesia. Princeton: Princeton University Press, 2000.

Hefner, Robert W. Making Modern Muslim the Politic of Islamic Education in Southeast Asia. Honolulu: University of Hawai Press, 2009.

Heryanto, Ariel, ed. Pop Culture in Indonesia: Fluid Identities in Post Authoritarian Politics. London: Routledge, 2008.

Hilmy, Masdar, "Whither Indonesia's Islamic Moderatism?", Journal of Indonesian Islam, volume 7, number 1 (2013): 24-48.

Hooker, M.B. (ed.). Islam in South-East Asia. Leiden: Brill, 1983.

Hoon, Chang You. Chinese Identity in Post-Suharto Indonesia: Culture, Politics, and Media. Brighton: Sussex Academic Press, 2008.

Ishwara, Luwi. Catatan-Catatan Jurnalisme Dasar. Jakarta: Penerbit Buku Kompas, 2007.

Jahja, H. Junus (ed.). Zaman Harapan bagi Keturunan Tionghoa. Jakarta:Yayasan Ukhuwah Islam, 1984.

Jahja, H. Junus. Islam di Mata WNI. Jakarta: Yayasan H. Karim Oei, 1995. Jahja, H. Junus. Masalah Tionghoa Di Indonesia: Asimilasi vs Integrasi. Jakarta: LPMP, 1999.

Kasali, Rhenald. Disruption. Jakarta: Gramedia Pustaka Utama, 2017.

Kung, Hans. Global Responsibility In Search of a New World Ethic. New York: Crossroad Publishing Company, 1991.

Latief, Hilman. Melayani Umat: Filantropi Islam dan Ideologi Kesejahteraan Kaum Modernis. Jakarta: PT Gramedia Pustaka Utama, 2010.

Lindsey, Tim and Helen Paulsacker (eds.). Chinese Indonesians: Remembering, Distorting, Forgeting. Singapore: Institute of Southeast Asian Studies, 2006. 
IJIMS: Indonesian Journal of Islam and Muslim Societies, Volume 8, Number 2, December 2018: 225-252

Lippmann, Walter. Opini Umum. Jakarta: Yayasan Obor Indonesia, 1998. Lombard, Denys. Nusa Jawa Silang Budaya. Jakarta: Gramedia, 2008.

Madjid, Nurcholish. Islam Kemodernan dan Keindonesiaan. Bandung: Mizan, 1997.

Magnis-Suseno, Franz. Etika Abad Kedua Puluh. Yogyakarta: Kanisius, 2006.

Mahfud, Choirul, "Lessons From Zheng He: Love of Peace and Multiculturalism”, in Chia Lin Sien\& Sally K Church (eds). Zheng He $\mathcal{E}$ the Afro-Asian World. Melaka: PERZIM and the International Zheng He Society in Singapore, 2012.

Mahfud, Choirul. Manifesto Politik Tionghoa di Indonesia. Yogyakarta: Pustaka Pelajar, 2013.

Mahfud, Choirul, "The Role of Cheng Ho Mosque: The New Silk Road, Indonesia-China Relations in Islamic Cultural Identity", Journal of Indonesian Islam, volume 8, number 1 (2014): 23-38.

Majalah Cheng Hoo, Majalah Dwi Bulanan Komunitas Muslim Tionghoa, Edisi 92, 2017.

Majalah Cheng Hoo, Majalah Dwi Bulanan Komunitas Muslim Tionghoa, Edisi 93, 2017.

Majalah Cheng Hoo, Majalah Dwi Bulanan Komunitas Muslim Tionghoa, Edisi 94, 2017.

Majalah Cheng Hoo, Majalah Dwi Bulanan Komunitas Muslim Tionghoa, Edisi 95, 2017.

Muljana, Slamet. Runtuhnya Kerajaan Hindu-Jawa dan Timbulnya Negaranegara Islam di Nusantara. Yogyakarta: LKiS, 2005.

Muzzaki, Akhmad, "Negotiating Identity: The Cheng Hoo Mosque and The Ethnic Chinese Muslim in Post-Soeharto Indonesia", Chinese Southern Diaspora Studies, Volume 3, 2009.

Naisbitt, John \& Doris. China's Megatrends: 8 Pilar yang Membuat Dahsyat China. Jakarta: Gramedia Pustaka Utama, 2010.

Niam, Khoirun, "The Discourse of Muslim Intellectuals and Ulama' in Indonesia: A Historical Overview," Journal of Indonesian Islam, volume 4, number 2 (2010): 287-316.

Perkasa, Adrian. Orang-orang Tionghoadan Islam di Majapahit. Yogyakarta: Penerbit Ombak, 2012. 
Pong, David. (ed.) Encyclopedia of Modern China. Farmington Hills: Gale, Cengage Learning, 2009.

Poole, Ross. Nation and Identity. London: Routledge, 1999.

Pradana Boy ZTF, "Prophetic Social Sciences: Toward an Islamic-Based

Transformative Social Sciences," Indonesian Journal of Islam and Muslim Societies, volume 1, number 1 (2011): 95-121.

Pye, Lucian W. The Spirit of Chinese Politics. Cambridge: Harvard University Press, 1992.

Rafika Perdana, Fahmi. IntegrasiSosial Muslim Tionghoa: Studi Atas Partisipasi PITI Korwil Yogyakarta dalam Proses Pembauran. Yogyakarta: Mystico-PITI Korwil Yogyakarta, 2008.

Rattansi, James Donald and Ali Rattansi. Race, Culture, and Difference. London: Sage Publications, 1992.

Remmelink, Willem. The Chinese War and the Collapse of the Javanese State. Leiden: KITLV Press, 1994.

Ricklefs, Merle Calvin. A History of Modern Indonesia. London: Macmillan Education, 1988.

Schwartz, SJ (et al.). Handbook of Identity Theory and Research. London: Springer Science and Business Media, 2010.

Suaedy, Ahmad. (et.al.). Islam dan Kaum Minoritas: Tantangan Kontemporer. Jakarta: The Wahid Institute, 2012.

Sudibyo, Agus, Ibnu Hamad dan Muhammad Qodari. Kabar-kabar Kebencian, Prasangka Agama di Media Massa. Jakarta: ISAI, 2001.

Suryadinata, Leo. Southeast Asian Chinese: The Socio-Cultural Dimension. Singapore: Times Academic Press, 1995.

Tan, Ta Sen. Cheng Ho and Islam in Southeast Asia. Singapore: Institute of Southeast Asian Studies, 2009.

Tan, Melly G. Etnis Tionghoa di Indonesia. Jakarta: Yayasan Obor Indonesia, 2008.

Tanggok, M. Ikhsan (et.al.). Menghidupkan Kembali Jalur Sutra Baru Format BaruHubungan Islam Indonesia dan China. Jakarta: Gramedia Pustaka Utama, 2010.

Tebba, Sudirman. Mengenalkan Wajah Islam yang Ramah: Sufi-sufi Jawa. Jakarta: Pustaka Irvan, 2007. 
IJIMS: Indonesian Journal of Islam and Muslim Societies, Volume 8, Number 2, December 2018: 225-252

Weng, Hew Wai. Chinese Ways of Being Muslim: Negotiating Ethnicity and Religiosity in Indonesia. Copenhagen: NIAS Press, 2017.

Wijayakusuma, Hembing. Muslim Tionghoa Cheng Ho. Jakarta: Yayasan Obor Indonesia, 2000.

Wibowo, I (ed.). Harga yang Harus Dibayar: Sketsa Pergulatan Etnik Cina di Indonesia. Jakarta: Gramedia Pustaka Utama, 2000.

Zhou, Jinghao. China's Peaceful Rise in a Global Context: A Domestic Aspect of China's Road Map to Democratization. Lanham-Maryland: Lexington Books, 2010. 